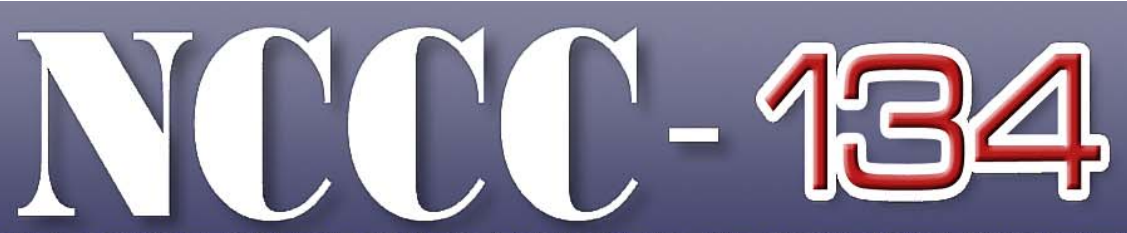

APPLIED COMMODITY PRICE ANALYSIS, FORECASTING AND MARKET RISK MANAGEMENT

\title{
The Adequacy of Speculation in Agricultural Futures Markets: Too Much of a Good Thing? \\ by
}

Dwight R. Sanders, Scott H. Irwin, and Robert P. Merrin

Suggested citation format:

Sanders, D. R., S. H. Irwin, and R. P. Merrin. 2008. “The Adequacy of Speculation in Agricultural Futures Markets: Too Much of a Good Thing?” Proceedings of the NCCC-134 Conference on Applied Commodity Price Analysis, Forecasting, and Market Risk Management. St. Louis, MO. [http://www.farmdoc.uiuc.edu/nccc134]. 


\title{
The Adequacy of Speculation in Agricultural Futures Markets: Too Much of a Good Thing?
}

\author{
Dwight R. Sanders \\ Scott H. Irwin \\ Robert P. Merrin* \\ Paper presented at the NCCC-134 Conference on Applied Commodity Price \\ Analysis, Forecasting, and Market Risk Management \\ St. Louis, Missouri, April 21-22, 2008
}

Copyright 2008 by Dwight R. Sanders, Scott H. Irwin, and Robert P. Merrin. All rights reserved. Readers may make verbatim copies of this document for non-commercial purposes by any means, provided that this copyright notice appears on all such copies.

*Dwight R. Sanders is an Associate Professor of Agribusiness Economics at Southern Illinois University, Carbondale, Illinois. Scott H. Irwin is the Laurence J. Norton Chair of Agricultural and Consumer Economics at the University of Illinois, Urbana, Illinois. Robert P. Merrin is a Ph.D. student in the Department of Finance at Universiteit Maastricht, Netherlands. 


\title{
The Adequacy of Speculation in Agricultural Futures Markets: Too Much of a Good Thing?
}

\author{
Practitioner's Abstract
}

Long-only commodity index funds have been blamed by other futures market participants for inflating commodity prices, increasing market volatility, and distorting historical price relationships. Much of this criticism is leveled without any formal empirical support or even cursory data analyses. The Commodity Futures Trading Commission makes available the positions held by index funds and other large traders in their Commitment's of Traders report. In this research, we make an initial assessment of the size and activity of index funds in traditional agricultural futures markets. The results suggest that after an initial surge from early 2004 through mid-2005, index fund positions have stabilized as a percent of total open interest. Speculative measures-such as Working's $T$-suggest that long-only funds may provide a benefit in markets traditionally dominated by short hedging.

Key Words: Commitment's of Traders, index funds, commodity futures markets

\section{Introduction}

In a series of classic papers, Working (1953 19541960 1962) argued that futures markets are primarily hedging markets and that speculators tend to follow hedging volume and liquidity. If this assertion is true, then a key performance indicator in futures markets is the level of speculation relative to hedging. Working termed this "the market balance concept." A common concern expressed in writings on agricultural futures markets over the following two decades was that speculation on futures markets was not large enough to accommodate hedging pressure (e.g., Hieronymus 1971; Peck 1980; Leuthold 1983). In today's world of managed futures, hedge funds, and long-only commodity index investments, that concern seems more than a little dated. Indeed, many would argue that today's speculative trade in agricultural futures markets is the proverbial tail wagging the dog. For example, recent growth in long-only commodity index funds has led some market participants to claim that excessive speculation is creating "price distortions" and potentially disrupting traditional cash-futures convergence patterns (Morrison 2006; Henriques 2008)

The nature and structure of agricultural futures markets has changed dramatically since the pioneering research of Working. The days of the dentist-speculator from Dubuque dabbling in the pork bellies futures market are long gone. Fueled by academic evidence showing that commodity futures portfolios can generate returns comparable to equities (e.g., Gorton and Rouwenhorst 2006), the investment industry has developed products that allow individuals and institutions to "invest" in commodities through over-the-counter swaps and structured notes that are linked to popular commodity indices, such as the Goldman Sachs Commodity Index (Acworth 2005). Domanski and Heath (2007) term this the "financialisation" of commodity markets.

The conventional method of monitoring speculative positions in futures markets is through the Commodity Futures Trading Commission's (CFTC) Commitments of Traders (COT) reports. 
Working (1960) defined a speculative index to measure the adequacy of non-commercial positions to essentially off-set the hedging positions held by commercial traders. Working's speculative index has been used in several studies to examine grain and livestock futures markets for adequate speculative activity (Working 1960; Nathan Associates 1967; Labys and Granger 1970; Peck 1982; Leuthold 1983). Generally, these academic studies concluded that speculation in agricultural futures markets was not excessive. For example, Peck found that "... wheat, corn, and soybean markets are characterized by very low relative levels of speculation" (p. 1040) and Leuthold found no "...evidence to indicate that the levels of speculation in livestock have led to increased price variability as often alleged in the popular press" (p. 133). Now, over 25 years later, allegations about the size and impact of speculators in commodity markets have once again arisen within industry (Sjerven 2008), government (CHSGA 2008), and the academy (AFPC 2008). Clearly, additional research efforts are needed to better understand the role and potential impact of speculators in general and long-only funds in particular.

The objective of this paper is to re-visit the "adequacy of speculation" debate in agricultural futures markets, bringing new data to the task. Specifically, COT data-including positions held by longonly index funds and commercial banks as reported in the Commodity Index Trader (CIT) reportwill be closely examined to better measure the nature of speculation in grain and livestock futures markets. The first part of the analysis will provide an overview of the relative trading activity of commercial, non-commercial, and non-reporting traders. Particular attention will be given to recent trends indicative of a shift in speculative activity, perhaps associated with the growth in long-only commodity funds. The second part of the analysis will use Working's speculative index to examine the "adequacy" of speculation relative to hedging demands in agricultural futures markets since the mid-1990s. The third part focuses on a separate CFTC report_-Banker Participation in Futures Markets - to provide a unique look at the increase in long-only index activity. The focus will be on summarizing the data and highlighting recent trends to provide a more objective assessment of speculative activity.

\section{Data}

\section{Traditional COT Report}

The traditional COT report provides a breakdown of each Tuesday's open interest for markets in which 20 or more traders hold positions equal to or above the reporting levels established by the CFTC. ${ }^{1}$ Note that open interest for a given market is aggregated across all contract expiration months. The weekly reports for Futures-and-Options-Combined Commitments of Traders are released every Friday at 3:30 p.m. Eastern Standard Time.

Reports are available in both a short and long format. The short report shows open interest separately by reportable and non-reportable positions. For reportable positions, additional data are provided for commercial and non-commercial holdings, spreading, changes from the previous report, percentage of open interest by category, and number of traders. The long report, in addition to the information in the short report, also groups the data by crop year, where appropriate, and shows the concentration of positions held by the largest four and eight traders. 
Using the information in the short report, non-commercial open interest is divided into long, short, and spreading; whereas, commercial and non-reporting open interest is simply divided into long or short. The following relation explains how the market's total open interest (TOI) is disaggregated:

$$
\underbrace{[N C L+N C S+2(N C S P)]+[C L+C S]}_{\text {Reporting }}+\underbrace{[N R L+N R S]}_{\text {Non-Reporting }}=2(T O I)
$$

where, NCL, NCS, and NCSP are non-commercial long, short, and spreading positions, respectively. CL (CS) represents commercial long (short) positions, and NRL (NRS) are long (short) positions held by non-reporting traders. Reporting and non-reporting positions must sum to the market's total open interest (TOI), and the number of longs must equal the number of short positions.

A frequent complaint about the traditional COT data is that the trader designations may be somewhat muddled (e.g., Ederington and Lee 2002). For speculators, there may be an incentive to self-classify their activity as commercial hedging to circumvent speculative position limits. In contrast, there is little incentive for traders to desire the non-commercial designation. So, it is often thought that the non-commercial category is a relatively pure subset of reporting speculators (Sanders, Boris, and Manfredo 2004). The available evidence about the composition of nonreporting traders is dated (Working 1960; Larson 1961; Rutledge 1977-78; Peck 1982), so little is known about this group other than their position size is less than reporting levels.

While there may be some incentive for reporting traders to desire the commercial designation, the CFTC implements a fairly rigorous process - including statements of cash positions in the underlying commodity - to ensure that commercial traders have an underlying risk associated with their futures positions. However, in recent years industry participants began to suspect that these data were "contaminated" because the underlying risk for many reporting commercials were not positions in the actual physical commodity (CFTC 2006a 2006b). Rather, the reporting commercials were banks and other swap dealers hedging risk associated with over-the-counter (OTC) derivative positions.

For example, a commercial bank may take the opposite side of a long commodity swap position desired by a customer. ${ }^{2}$ The commercial bank, not wanting the market risk, will then buy commodity futures contracts to mitigate their market exposure associated with the swap position. Technically, the bank's position is a bona fide hedge against an underlying risk in the swap market. Yet, the bank is clearly not a commercial hedger in the traditional sense. Indeed, the third party or bank customer who initiated the position may be hedging or speculating; their motives are not necessarily known even to the swap dealer. However, the OTC swap positions that can be easily identified are those "... seeking exposure to a broad index of commodity prices as an asset class in an unleveraged and passively-managed manner" (CFTC 2008). In this instance, the bank customer is essentially long a commodity index such as the Goldman Sachs Commodity Index (GSCI) via a swap with the bank. The bank then mitigates their long GSCI exposure by hedging each commodity component (e.g., crude oil, corn, and live cattle) in the respective individual futures markets. Because the banks and swap dealers can easily identify swaps associated with commodity indices, it allows the CFTC to further segregate the reporting trader categories to include "index traders." 


\section{Commodity Index Traders (CIT) Report}

Starting in 2007 - in response to complaints by traditional traders about the rapid increase in longonly index money flowing into the markets - the CFTC released supplemental reports which break out the positions of index traders for 12 agricultural markets. According to the CFTC, the index trader positions reflect both pension funds that would have previously been classified as noncommercials as well as swap dealers who would have previously been classified as commercials hedging OTC transactions involving commodity indices.

The CFTC readily admits that this classification procedure has flaws and that "... some traders assigned to the Index Traders category are engaged in other futures activity that could not be disaggregated....Likewise, the Index Traders category will not include some traders who are engaged in index trading, but for whom it does not represent a substantial part of their overall trading activity" (CFTC 2008). Regardless, the data are an improvement over the more heavily aggregated traditional COT classifications, and they should provide some new insights as to trader activity.

The CIT data are released in conjunction with the traditional COT report showing combined futures and options positions. The index trader positions are simply removed from their prior categories and presented as a new category of reporting traders. The CIT data includes the long and short positions held by commercials (less index traders), non-commercials (less index traders), index traders, and non-reporting traders.

While the data for the traditional COT trader positions are available for each week from March 21, 1995 through April 15, 2008 (683 observations), the CIT data are only available for the period covering January 3, 2006 through April 15, 2008 (120 observations). Both reports reflect combined futures and options positions, where options are adjusted to the delta-equivalent futures position. The reports show traders' holdings as of Tuesday's market close.

\section{Bank Participation (BP) Data}

Well before there were concerns about long-only index funds, the U.S. Federal Reserve Board desired to monitor the participation of commercial banks in futures markets (Huhman 2006). In response, the CFTC compiled the Bank Participation in Futures Markets report (BP). The BP report contains the positions held by commercial banks in futures markets where there are at least five banks with open positions. A Bank Participation in Options Markets report is also compiled, but it does not adjust positions to a delta-equivalent basis, reducing its usefulness. The $B P$ reports are released monthly on a reporting date that is aligned with the $C O T$ reports. However, the $B P$ reports are independent and they are not technically part of the COT reports.

The $B P$ report started to sporadically show positions in the grain markets by mid-2003, indicating that at least five commercial banks were participating in the grain futures markets during some months in that year. By late 2004, there are consistent data available for the primary grain markets representing on-going participation by at least five commercial banks each month. Consistent participation by commercial banks in the livestock futures markets began in mid-to-late- 2005 . 
Importantly, positions shown in the $B P$ report are a pure subset of the traditional COT commercial category. Moreover, it is generally thought that the commercial bank positions are mostly hedges against OTC swaps on commodity indices (Huhman 2006). In which case, there should be a strong correspondence between $B P$ data and the CIT data. Because the BP data actually have a longer available history than the $C I T$ data, the $B P$ data will be used to supplement the analysis of index trader positions for certain markets.

\section{Summary Statistics and Trends}

In this section the summary statistics and trends are presented for various measures of market participation and activity. When possible, the entire data set from 1995 forward is used. However, in many instances, the focus is on the period from January 2006 through April 2008 for which the CIT data are available. Markets included in the analysis are as follows: corn, soybeans, soybean oil, CBOT wheat, KCBOT wheat, cotton, live cattle, feeder cattle, and lean hogs. ${ }^{3}$

\section{Changes in Activity}

Agricultural futures markets experienced rapid growth starting in late 2004. The open interest for many agricultural futures markets doubled or even tripled from late 2004 through 2006. For example, the CBOT wheat futures market saw open interest increase $275 \%$ from June 2004 to June 2006 (see Figure 1). Other markets, such as soybeans, have continued to see rapid growth in open interest into 2008 (see Figure 2). The increase in open interest may be attributed to electronic trading and easier market access, an inflationary environment for many commodity markets, or potentially an increase in the use of commodity futures as an investment tool and inflation hedge.

Using the data from the traditional COT report, the positions of the trader groups - as measured by their percent of total open interest - are examined for the 1995-2005 and 2006-2008 periods. As shown in Table 1, uniformly across all markets, the relative size of non-reporting traders has declined. For example, non-reporting traders in CBOT wheat comprised, on average, $22 \%$ of the open interest from 1995-2005, but only $10 \%$ of the open interest from 2006-2008. On the flipside, non-commercials increased their share of the open interest in every market, and the commercials' share of the open interest increased in all but three markets (KCBOT wheat, soybeans, and cotton). The specific trends by COT category for CBOT wheat are shown in Figure 3.

Clearly, the agricultural futures markets have changed since 2004. First, the total level of open interest has increased markedly. Second, the role of smaller (non-reporting) traders has diminished, while there has been a relative increase in market positions held by reporting traders-especially in the commercial category. In the next section, we use the CIT data to gain further insights into the market composition.

\section{Index Trader Participation}

The sample period from January 2006 through April 2008 is available for analyzing the CIT data. The CIT data are first compared to the original COT classifications to determine from which traditional COT category the index positions are extracted. The results are shown in Table 2. 
As expected, index trader positions were primarily aggregated within the commercial long positions. Across markets, roughly $85 \%$ of the index trader positions were previously contained in the long commercial category of the traditional COT reports. The other $15 \%$ is primarily from the long non-commercial category. This suggests that the majority of long-only commodity index positions are initially established in the OTC markets, then the underlying position is transmitted to the futures market by the swap dealers (including both commercial and investment banks) hedging their OTC exposure.

One of the primary concerns expressed by the industry is the magnitude of the commodity index activity. In a recent Barron's article, one analyst quipped that "index funds account for $40 \%$ of all bullish bets on commodities...the index funds hold about $\$ 211$ billion worth of bets on the buy side of U.S. markets." (Epstein 2008). Presumably, the sheer size of the index fund positions may allow them to distort prices or price relationships across markets.

A detailed view of position size as a percent of total open interest is provided in Table 3 . Over the sample period, index traders do make up a surprisingly large portion of certain markets. In particular, index traders are over $20 \%$ of the open interest in live cattle, lean hogs and CBOT wheat. In all other markets, index trader positions tend to be between $10 \%$ and $15 \%$. While this is not an insignificant share of the open interest, in no market is the index share larger than either the noncommercial or commercial categories. Rather, the index share of open interest tends to be closer to that of the non-reporting traders.

Importantly, the data show that index traders' percent of total open interest has been relatively stable over the sample period. This is demonstrated for CBOT wheat in Figure 4, where the index traders' share of the market has fluctuated in a fairly narrow range between $20 \%$ and $25 \%$ over the last two years. As shown in Figure 5, the same is true for both corn and soybeans, where the index funds percent of open interest has not exceeded 15\% since 2006. Similarly, the livestock futures markets (Figure 6) show that as a percent of total open interest, index fund positions have been relatively stable over the sample period. The exception seems to be live cattle which trended higher in mid-2007 and then stabilized around $23 \%$.

An additional criticism of index funds is their disproportionate presence on the long side of the market, stemming from the fact they are "long-only." To examine this idea more closely, we first examine the percent net long position held by each trader category in the CIT data. The percent net long position is simply defined by trader category as the net position (long positions minus the short positions) divided by the total positions held (see Sanders, Manfredo, and Boris). For example, a long position of 1,000 and a short position of 2,000 would yield a percent net long of -33\% $((1,000$ $2000) / 3000$ ), indicating that the net position held by that trader category is $33 \%$ short.

The percent net long for each trader group is calculated over the sample period and presented in Table 4. As expected, index traders are $90 \%-98 \%$ net long in each market. Likewise, the commercial category is $20 \%-65 \%$ net short reflecting the traditional short hedging of producers, commercial processors, first handlers, and warehouses. Interestingly, for two of the markets with high levels of index participation-CBOT wheat and lean hogs - the index funds are the only category that held a net long position over the sample period. 
To more closely examine each side of the market, the relative size of the long and short side of the markets is presented in Table 5 for each trader category. Since index funds are almost exclusively long, their percent of the market roughly doubles when only considering the long side of the market as opposed to total positions. For example, index funds are $21 \%$ of the total positions in CBOT wheat, but they are $40 \%$ of the long positions in CBOT wheat. Across the markets, index funds range from $20 \%$ (KCBOT wheat) to $44 \%$ (lean hogs) of the long positions in the market. In both CBOT wheat and lean hogs, the index funds held a larger portion of long positions than any other trader group. With the exception of feeder cattle, the short-side of the market is mostly dominated by commercial hedgers.

The CIT data clearly show that index funds are a large portion of the open interest in some agricultural commodity markets. In lean hogs and CBOT wheat, the index funds tend to be the largest category on the long-side of the market. While this attests to the sheer size of their market participation, it does not necessarily imply that they have a price impact.

\section{Traders and Position Size}

The CIT data (as well as the COT data) include information on the number of reporting traders in each category. From this, we can determine the number of reporting index traders in each market as well as the average trader's position size relative to the other trader categories.

Table 6 shows the average number of reporting traders over the sample period from January, 2006 to April, 2008. The total number of reporting traders for the market is shown as well as the number in each trader category. A reporting trader can appear in more than one category; therefore, the sum of each category need not equal the total reporting traders in that market.

From the data in Table 6, it is immediately apparent that there are relatively few reporting index traders. The corn, CBOT wheat, and soybean futures markets have 24 long index traders with reportable positions, while the KCBOT wheat futures market has 15 reporting long index traders. There are a few index traders with short positions, but these most likely reflect some of the positions held by long index traders that the CFTC could not disaggregate. Across most of the markets, there does not seem to be any glaring disparities between the number of reporting commercial and non-commercial traders.

Table 7 shows the average reporting trader's position size by category over the sample period. The average position size is simply calculated as the positions held by that category divided by the number of reporting traders in that category. Because a trader may appear in more than one category, the calculated average position size is likely lower than the actual.

Not surprisingly, given the fairly large percent of open positions held by index traders (Table 3) and the relatively few number of reporting index traders (Table 7), the average index trader's position size is relatively large. For example, in the corn futures market, the average long index trader has a position of 16,805 contracts which is more than 10 times the size of the average long position held by either commercials or non-commercials. This finding is consistent: long index traders have the largest average position size. 
For comparison, Table 7 also shows the reporting levels and speculative limits for each market. Clearly, the average position size of all reporting trader categories is larger than the required reporting level. However, the average position size held by non-commercials generally falls far short of the speculative limits. This suggests that among non-commercial reporting traders there is likely a wide variation in position sizes, where some non-commercial positions must approach the speculative limits.

Commercial traders who are bona fide hedgers are not subject to the positions limits. Yet, in no market does the average position size held within the commercial category exceed the speculative limit. However, the index traders - who most likely are categorized as commercial hedgers in the original COT data - come much closer to the speculative limits on average. In fact, the average long index trader in CBOT wheat holds more than 2,000 contracts in excess of the speculative limit of 6,500. While this is legal, it does provide some indirect evidence that speculators or investors are able to use OTC instruments and commercial hedge exemptions to surpass speculative position limits.

Based on the information in Tables 6 and 7, it is clear that index traders number relatively few; but, they hold very large long positions. The average position size for an index trader can be more than 10 times the size of the average position held by other trader groups. Since index funds are longonly and not known for rapid-fire trading, it is not clear that this presents a problem. Although, it does support the notion that when the index funds "roll" positions to a new contract month it is a much anticipated event (e.g., the "Goldman roll") and associated with considerable trading volume.

\section{Speculative Measures}

Working (1960) developed his speculative " $T$ " index to measure the amount of speculation to "carry" hedging after accounting for the amount of long and short hedging that offset each other. Working's speculative index has been used in several studies to examine grain and livestock futures markets for adequate speculative activity (Working 1960; Nathan Associates 1967; Labys and Granger 1970; Peck 1982; Leuthold 1983). Nearly all prior research is concerned about a lack of sufficient speculative activity to support hedging demands in the marketplace. While this notion seems at odds with the current market environment, Working's T still provides an objective measure of speculative activity.

Working's T is easily calculated using the traditional COT trader categories:

$$
\begin{array}{ll}
\mathrm{T}=1+\mathrm{SS} /(\mathrm{HL}+\mathrm{HS}) & \text { if }(\mathrm{HS} \geq \mathrm{HL}) \\
\text { or } & \\
\mathrm{T}=1+\mathrm{SL} /(\mathrm{HL}+\mathrm{HS}) & \text { if }(\mathrm{HL}>\mathrm{HS})
\end{array}
$$

where open interest held by speculators (non-commercials) and hedgers (commercials) is denoted as follows, 


$$
\begin{array}{ll}
\mathrm{SS}=\text { Speculation, Short } & \mathrm{SL}=\text { Speculation, Long } \\
\mathrm{HL}=\text { Hedging, Long } & \mathrm{HS}=\text { Hedging, Short }
\end{array}
$$

As an example of the calculation and interpretation of Working's speculative $\mathrm{T}$ index, consider the intuitive case where $\mathrm{HL}=0$; then, $\mathrm{T}=\mathrm{SL} / \mathrm{HS}=1+(\mathrm{SS} / \mathrm{HS}) .{ }^{4}$ It follows, if long speculation (SL) just equals short hedging (HS), then T equals its minimum value of 1.00 , where the level of speculation is just sufficient to off-set hedging needs. Now, consider if $\mathrm{HL}=0, \mathrm{SS}=10, \mathrm{HS}=100, \mathrm{SL}=110$, then $\mathrm{T}$ equals 1.10 or there is $10 \%$ speculation in excess of that necessary to meet hedging needs. Working is careful to point out that what may be "technically an 'excess' of speculation is economically necessary" for a well-functioning market (1960 p. 197).

As noted by several authors (e.g., Leuthold 1983), Working's T suffers from the problem of how to classify the non-reporting traders. Non-reporting traders can be classified as speculators, creating an upper bound on the speculative index. Or, they can be classified as hedgers, creating a lower bound on the index. With either of these approaches however, the index will be impacted through time if the proportion of non-reporting traders in a market changes. As shown in Table 1 and Figure 3 , diminishing levels of non-reporting trader positions is clearly a problem over our sample period. So, we follow the advice of Rutledge (1977-78) and initially allocate the non-reporting traders' positions to the commercial, non-commercial, and index trader categories in the same proportion as that which is observed for reporting traders.

Working's $\mathrm{T}$ is calculated for a number of sub-periods using the traditional COT data. For the later sample in which CIT data are available, Working's $\mathrm{T}$ is calculated using both the traditional COT categories and the CIT data. When using the CIT data, the index traders are re-grouped with the non-commercial traders. That is, the index trader positions are considered speculative.

The values for Working's $\mathrm{T}$ are presented in Table 8 . The speculative indices reported do not seem extraordinarily high in any sub-period from 1995 through 2008 using the traditional COT data. Corn futures average 1.08 which suggests that there is only $8 \%$ more speculation than the minimum needed to offset hedging needs. The highest speculative index within the grains is CBOT wheat at 1.15 , and for livestock it is 1.38 recorded for feeder cattle. Average index values across the nine markets range from 1.12 to 1.14 for the different sub-periods, implying that speculation was barely large enough to balance short hedging demands. In addition, there is no discernable trend in the indexes across the different sub-periods. This is demonstrated in more detail in Figure 7 using the traditional COT trader classifications for CBOT wheat.

In the last column of Table 8, Working's T is re-calculated for the 2006-2008 sample period by reclassifying index traders as speculators. Because commercial hedgers are predominantly net short in each market, they require long speculators to "carry" their hedging. So, by re-categorizing the long-only index funds into the non-commercial category, Working's T essentially is shifted upward in each market. Even with this adjustment, the average speculative index for the nine markets only increases from 1.14 to 1.27. The largest increase, from 1.38 to 1.67 , occurs in feeder cattle.

Further perspective is provided by comparing Working's speculative index in recent periods with those reported by other researchers for earlier periods. Table 9 presents the historical estimates from four previous studies (Working 1960; Labys and Granger 1970; Peck 1982; Leuthold 1983) 
along with the upper and lower bounds for the CIT adjusted data from 2006-2008. ${ }^{5}$ The upper (lower) range results from assuming that non-reporting traders are speculators (hedgers). ${ }^{6}$ Nonreporting traders are a proportionately smaller part of the market than they have been historically (see Table 1), resulting in a smaller range of "T" values than recorded in previous work. Therefore, the calculation of Working's $T$ in recent years is not particularly sensitive to the speculator or hedger classification imposed on non-reporting traders. The exception is feeder cattle, where nonreporting traders still represent over $30 \%$ of the total open interest.

Comparing the historical estimates in Table 9 with our results using the traditional COT in Table 8, one is struck by the relatively low levels of speculation throughout 1995-2008. The average values for the speculative indices range from 1.12 to 1.14 across the different sub-periods, about equal to or smaller than the averages from the historical estimates spanning the late 1940s to the late 1970s, with the exception of Leuthold's upper bound estimates in livestock futures markets. As noted earlier, a common concern expressed in previous studies was that speculation on futures markets was not large enough to accommodate hedging pressure. The results for 1995-2008 are wholly consistent with this historical concern regarding agricultural futures markets. Peck's (1980) conclusions are especially relevant in this regard. For example, she was concerned about the inadequacy of speculation in CBOT wheat from 1972-1977 after finding a speculative index ranging from 1.094 to 1.323 . Peck viewed this level of speculation as inadequate when compared to an index of 1.355 to 1.891 from 1947-1971, a period that "would hardly be characterized as speculative" (p. 1041). Likewise, Peck (1980) reports KCBOT wheat had a speculative index ranging from 1.009 to 1.045 which was "manifestly inadequate" (p. 1043). Across the sub-periods over 1995-2008, CBOT wheat had an average speculative index of 1.14 and KCBOT wheat averaged 1.07.

The final column of Table 9 shows upper and lower bounds for Working's T over 2006-2008 using the CIT adjusted data. Again, there is little evidence that current index levels are deviating from historical norms, even after accounting for index trader positions. For instance, the range reported for live cattle futures (1.13-1.60) is generally lower than those reported by Peck (1.568-2.173) and Leuthold (1.05-2.34). Interestingly, the values reported for cotton (1.27) and soybean oil (1.14) by Working for the 1954-1958 period are generally at the upper end of the recent range reported for 2006-2008. There is no pervasive evidence that current speculative levels, even after accounting for index trader positions, are in excess of those recorded historically for agricultural futures markets.

Based on Working's speculative T index, it would seem that agricultural futures markets do not have a historically high level of speculative activity. However, in Working's day, a commercial trader was most probably merchandising the underlying physical commodity, not hedging OTC swaps. The current "commercial" category may still be contaminated by swap dealers who are hedging OTC swaps not used for commodity index investments. Moreover, Working and others strongly maintained that futures markets were hedging markets, where speculators enter the market in response to hedging pressures. The "financialization" of commodity markets opens this basic tenant to debate and may bring into question the appropriateness of traditional speculative measures. 


\section{Bank Participation (BP)}

In a monthly report separate from the COT and CIT reports, the CFTC reveals the participation of commercial banks in the commodity futures markets. There must be at least five commercial banks participating in the market on the "as of" date for that market to be included in the Bank

Participation in Futures Markets (BP) report. Most agricultural futures market begin to show up sporadically in the monthly $B P$ reports in 2003 and then more consistently from 2005 forward. It is generally thought that the bank participation reflects hedging OTC commodity index swaps. So, to facilitate comparison to the CIT data, the $B P$ summary statistics are calculated over the same subsample from January 2006 through April 2008.

As shown in Table 10, the average number of banks participating in the agricultural commodity markets ranges from the minimum reporting level of 5 in feeder cattle to 14 in CBOT wheat. However, much like the CIT, the banks have a surprisingly large portion of open interest, holding $9 \%$ of the futures-only open interest in CBOT wheat. Likewise, the banks individually hold very large long positions. For instance, the average commercial bank's long position in CBOT wheat was 4,970 contracts, second in size only to the 8,597 average for all CIT traders (see Table 4).

To further compare the $B P$ traders to the CIT. We calculate the net position (long positions -short positions) for both the BP and CIT data. As shown in Figure 8 for the corn futures market, the net positions of these groups are closely related. This is generally true across all markets (not shown). So, it would appear that the $B P$ traders are a representative sample or subset of the CIT data. In the final column in Table 10, we calculate the percent of the CIT positions that would be held by the commercial banks included in the BP data. The percent of CIT positions that are likely commercial banks range from a low of $18 \%$ (feeder cattle) to a high of $35 \%$ (CBOT wheat). Because the $B P$ data are futures-only and the CIT data are combined futures and options, the position sizes and percent of CIT open interest reported in Table 10 represent a lower bound on the estimates.

The relationship between the $B P$ data and the CIT data is important because it justifies the use of the $B P$ data as a proxy for index trader activity in the period prior to 2006. Three markets - CBOT wheat, corn, and soybeans - have at least some BP data available for 2003. Any missing observations in 2003 and early 2004 are replaced by the positions reported in the prior month. Then, the banks' percent of futures-only open interest is calculated for each market and plotted from 2003-2008. If the BP positions are a representative sample of the overall CIT category, then the general trends in the $B P$ data can provide evidence in regards to the growth pattern of overall index fund activity.

The percent of futures-only open interest held by the commercial banks is plotted in Figure 9. Immediately it is clear that the most rapid increase in index participation appears to have occurred prior to the start of the CIT data history (prior to 2006). In the case of wheat, BP positions grew from $2 \%$ at the end of 2003 to almost $12 \%$ of the total futures open interest by May of 2005 . For all three of these markets, the rapid increase in bank positions - and presumably all index positionsoccurred during the 18 month period from early 2004 to mid-2005. Over that time period, $B P$ positions in corn futures climbed from less than $1 \%$ of futures-only open interest to over $6 \%$. 
The $B P$ data suggest that index activity showed the greatest growth (as a percent of the market) from early 2004 through mid-2005. It seems that this time period would be most prone to a market impact by index traders. In fact, as shown in Figure 10 for soybeans, the peak in the absolute position size comes well after the peak in the percent of open interest. This tendency is confirmed by looking at the actual CIT data over the 2006-2008 time period. As shown in Figure 11, the absolute index position in soybeans increased steadily through 2007, while the percent of open interest was fairly stable at around $13 \%$. Likewise, for lean hogs, the absolute position size held by index funds increased from 40,000 contracts to over 60,000 from late 2007 into early 2008 (see Figure 12). However, while there was some increase in the percent of open interest held by index traders, it did not exceed the $25 \%$ level seen in early 2006. This may indicate that the market is doing a better job of adjusting to index trader buying. As a result, index traders' percent of total open interest is relatively stable even though their absolute position size continues to increase.

The $B P$ positions are highly correlated with those of the $C I T$ positions; thus, the $B P$ positions provide a good proxy for index trader activity prior to 2006 . The $B P$ data suggest that index activity - as reflected by commercial banks - started in the grain futures markets in 2003 and grew rapidly from early 2004 to mid-2005. In most markets, index traders' percent of open interest peaked in early-2006, even though absolute position sizes continued to increase. These data suggest that the futures market may have went through a period of adjustment as this new type of trader entered the marketplace.

\section{Policy Implications}

In assessing the policy implications of this research, it is important to consider lessons from comparable episodes in the past. We submit that 1972-1975 is the last time period with comparable levels of structural change in commodity markets. U.S. and international commodity markets experienced a period of rapid price increases from 1972-1975, setting new all-time highs across a broad range of markets. In hindsight, economists generally consider this a period marked by rapid structural shifts such as oil embargoes, Russian grain imports, and the collapse of the Bretton Woods fixed exchange rate system (Cooper and Lawrence 1975).

It is particularly interesting to note that commodity price increases over 1972-1975 were often blamed on speculative behavior associated with the "tremendous expansion of trading in futures in a wide range of commodities" (Cooper and Lawrence 1975, p. 702). In fact, Labys and Thomas $(1975$, p. 287) motivate their research with words that could have been written in 2008 instead of 1975:

This paper analyses the instability of primary commodity prices during the recent period of economic upheaval, and determines the extent to which this instability was amplified by the substantial increase in futures speculation which also occurred. Of particular interest is the degree to which this speculation rose and fell with the switch of speculative funds away from traditional asset placements and towards commodity futures contracts.

Perhaps not surprisingly, Labys and Thomas found only a weak relationship between speculative activity and price instability. Still, public pressure to curb speculation resulted in a number of regulatory proposals and the upward adjustment of margin requirements (Rainbolt 1977; Tomek 
1985; Fishe and Goldberg 1986). The only consistent impact of higher margin requirements seems to be a decline in futures trading volume. The evidence that higher futures margins lower price variability is mixed, and there is no evidence that higher futures margins actually lower price levels (Peck and Budge 1987; Fishe and Goldberg 1986; Haradouvelis and Kim 1996). So, while higher margins may have reduced speculation - through lower open interest and reduced volume of trade - it seems to do little to cure the "problems" of high prices or price variability.

Like the 1972-1975 period, the 2006-2008 period has experienced a rapid increase in commodity price levels. Demand growth from developing nations, the diversion of row crops to biofuel production, and U.S. monetary policy are some of the economic fundamentals thought to underlie recent commodity price increases (Trostle 2008). The complex interplay between these factors and how they impact price expectations is often difficult to grasp in real-time. So, much like the early 1970's, the scapegoat for commodity price increases seems to have become the speculator, whose motives are much easier to impugn. Like spring following winter, calls are now being heard in the halls of the U.S. Congress for higher futures margins to curb speculation (CHSGA 2008). Given the potentially negative impacts of such policy decisions on the U.S. futures industry and on the proper functioning of the markets, it is critical to provide an objective characterization of the characteristics and potential impact of speculators in today's futures markets.

The present research does not directly address the impact of speculators on price behavior. However, it does suggest that current levels of speculation - given the markets hedging needs - are at historically normal levels. Indeed, Working's T in many agricultural futures markets are at levels that may have been associated with "inadequate" speculation in the past. If this is the case, then policy decisions aimed at curbing speculation may well be counter-productive in terms of price levels and market volatility. In particular, these policy initiatives could severely compromise the ability of futures markets to accommodate hedgers and facilitate the transfer of risk.

\section{Summary and Conclusions}

This research examines the size and activity of trader categories in the traditional Commodity Futures Trading Commission (CFTC) Commitments of Traders (COT) reports, the Commodity Index Trader (CIT) reports, and the Bank Participation (BP) reports. The data are closely examined for potential shifts or changes in the trader activity. In regards to the relative size of the index funds, they usually comprise between $10 \%-20 \%$ of the total open positions within most markets. However, because they are almost exclusively long, they tend to make up $20 \%-40 \%$ of the long-side of the market. In some markets (i.e., lean hogs, CBOT wheat), index funds are the predominant long position holder. The agricultural markets averaged fewer than 25 reporting long index traders over the 2006-2008 sample period. However, the long index traders have average positions that are more than 10 times the size of the typical non-commercial trader. For CBOT wheat, the average index position size exceeds the speculative limit.

A few notable trends or shifts in market participation are observed in the data. First, agricultural commodity futures markets have experienced a rapid increase in open interest that started in late 2004 and continues into 2008 for many markets. Second, from early 2005 to mid-2006 there was a dramatic increase in index funds' percent of total open interest (as shown by the BP data). For most markets, the index funds percent of open interest peaked in 2006 and has since stabilized, even 
though absolute position size continues to grow. Third, traditional speculative measures do not show any material changes or shifts over the sample period. Even after adjusting speculative indices for index fund positions, values are within the historical ranges reported in prior research.

While this analysis does not test for market impacts, it does provide some discussion points on that topic. First, if there is a market impact from index fund activity, it seems likely that it would have occurred during the period of rapid growth in 2004-2005. Second, the stabilization of the index funds' percent of total open interest may suggest that other traders have adjusted their strategies to better cope with this relatively new market participant. Third, Working's speculative index suggests that long-only index funds may in fact be beneficial in markets dominated by short hedging pressure. That is, they improve the adequacy of speculation by helping the market to "carry" unbalanced short hedging. However, the traditional notion that hedging begets speculating may need to be re-visited.

The ability of index funds to push prices away from fundamental value is almost accepted without criticism within the popular press. This notion seems unlikely given the ease with which other large non-commercial traders should be able to trade against index fund positions. Index funds do not attempt to hide their current position or their next move. Generally, funds that track a popular commodity index (e.g., GSCI) publish their mechanical procedures for rolling to new contract months. Moreover, they usually indicate desired market weightings when the index is re-balanced. So, the only uncertainty in their trading patterns may stem from the overall in-flow or out-flow of monies associated with the underlying investment vehicle (e.g., mutual fund). It seems unlikely that more flexible speculators would allow index funds to push prices away from fundamental values.

Much like in the last major episode of structural change in commodity markets in 1972-1975, some are blaming speculators for the recent increase in commodity prices. Proposals are once again surfacing to increase margins in an effort to curb "harmful" speculation in futures markets. Such policy decisions aimed at curbing speculation may well be counter-productive in terms of price levels or market volatility. In particular, these policy initiatives could severely compromise the ability of futures markets to accommodate hedgers and facilitate the transfer of risk.

There is certainly a need for additional research on the activity and market impact of all trader groups, especially index traders, using more disaggregated data (e.g., daily by contract maturity). Indeed, early research on futures markets stressed that an understanding of the size and motivation of various market participants was a crucial first step in understanding other, more advanced, market performance issues. 


\section{References}

Acworth, W. “Going Long on Commodities.” Futures Industry, May/June 2005, pp. 24-28.

Agricultural and Food Policy Center (AFPC). "The Effects of Ethanol on Texas Food and Feed." AFPC Research Report 08-1, April 2008. (http://www.afpc.tamu.edu/pubs/2/515/RR-08$\underline{01 . p d f})$

Commodity Futures Trading Commission (CFTC). "Comprehensive Review of the Commitments of Traders Reporting Program.” Federal Register, 71, FR 35627, June 21, 2006 a.

Commodity Futures Trading Commission (CFTC). "Commodity Futures Trading Commission Actions in Response to the "Comprehensive Review of the Commitments of Traders Reporting Program.” December 5, 2006b.

(http://cftc.gov/stellent/groups/public/@commitmentsoftraders/documents/file/noticeonsupp lementalcotrept.pdf)

Commodity Futures Trading Commission (CFTC). "About the Commitments of Traders." http://www.cftc.gov/marketreports/commitmentsoftraders/cot_about.html, accessed on May 15,2008 .

Committee on Homeland Security and Government Affairs (CHSGA), U.S. Senate. "Lieberman, Collins Say Commodities Market Speculation Contributes to High Cost of Food, Oil." May 20, 2008, http://hsgac.senate.gov/public/index.cfm?Fuseaction=PressReleases.Detail\&PressRelease id $=5 \mathrm{~b} 4235 \mathrm{c} 6-\mathrm{a} 484-4 \mathrm{a} 0 \mathrm{a}-9753-288 \mathrm{ae} 81 \mathrm{~b} 2 \mathrm{a} 54 \&$ Month $=5 \&$ Year=2008\&Affiliation=C, accessed on May 27, 2008.

Cooper, R.N., and R.Z. Lawrence. "The 1972-75 Commodity Boom.” Brookings Papers on Economic Activity 3(1975):671-723.

Domanski, D., and A. Heath. "Financial Investors and Commodity Markets." Bank for International Settlements Quarterly Review, March 2007, pp. 53-67.

Nathan Associates, Inc. "Margins, Speculation, and Prices in Grain Futures Markets." Special Report, Economic Research Service, U.S. Department of Agriculture, 1967.

Ederington, L., and J.H. Lee. "Who Trades Futures and How: Evidence from the Heating Oil Market.” Journal of Business 75(2002):353-373.

Epstein, G. “Commodities: Who's Behind the Boom?” Barron’s, March 31, 2008. (http://setup1.barrons.com/article/SB120674485506173053.html).

Fenton, J., and G. Martinaitas. "Large Trader Reporting: The Great Equalizer." Futures Industry, July/August 2005, pp. 34-39. 
Fishe, R.P.H., and L.G. Goldberg. "The Effects of Margins on Trading in Futures Markets.” Journal of Futures Markets 6(1986):261-271.

Gorton, G., and K.G. Rouwenhorst. "Facts and Fantasies about Commodity Futures." Financial Analysts Journal 62(2006):47-68.

Hardouvelis, G.A., and D. Kim. "Price Volatility and Futures Margins." Journal of Futures Markets 16(1996):81-111.

Henriques, D.B. “Odd Crop Prices Defy Economics.” New York Times, March 28, 2008, pp. C1.

Hieronymus, T.A. Economics of Futures Trading for Commercial and Personal Profit. New York, NY: Commodity Research Bureau, 1971.

Huhman, J. "Personal Communication." Commodity Futures Trading Commission, Division of Market Oversight, October 2006.

Hull, J.C. Options, Futures, and Other Derivatives, $4^{\text {th }}$ Edition. Upper Saddle River, NJ: Prentice Hall, 2000.

Labys, W.C., and C.W.J. Granger. Speculation, Hedging and Commodity Price Forecasts. Lexington, MA: Heath Lexington Books, 1970.

Labys, W.C., and H.C. Thomas. "Speculation, Hedging and Commodity Price Behavior: An International Comparison." Applied Economics 7(1975):287-301.

Larson, A.B. "Estimation of Hedging and Speculative Positions in Futures Markets." Food Research Institute Studies 2(1961):203-212.

Leuthold, R.M. "Commercial Use and Speculative Measures of the Livestock Commodity Futures Markets." Journal of Futures Markets 3(1983):113-135.

McDonald, W.E., and S.K. Freund. "The CFTC's Large Trader Reporting System: History and Development." Business Lawyer 38(1983):917-953.

Morrison, K. "US Wheat Futures at Nine-Year Peak." Financial Times, September 29, 2006, http://www.ft.com, accessed on October 19, 2006.

Peck, A.E. "The Role of Economic Analysis in Futures Market Regulation." American Journal of Agricultural Economics 62(1980): 1037-1043.

Peck, A.E. "Estimation of Hedging and Speculative Positions in Futures Markets Revisited." Food Research Institute Studies 18(1982):181-195.

Peck, A.E., and C. Budge. "The Effects of Extraordinary Speculative Margins in the 1947-48 Grain Futures Markets." Food Research Institute Studies 20(1987):165-180. 
Rainbolt, J.V. "Regulating the Grain Gambler and His Successors." Hofstra Law Review 6(1977):1-25.

Rutledge, D.J.S. "Estimation of Hedging and Speculative Positions in Futures Markets: An Alternative Approach.” Food Research Institute Studies 16(1977-78):205-211.

Sanders, D.R., K. Boris, and M. Manfredo. "Hedgers, Funds, and Small Speculators in the Energy Futures Markets: An Analysis of the CFTC's Commitments of Traders Reports." Energy Economics 26(2004):425-445.

Sjerven, J. "Futures Markets Users Struggle: Commodities Attract Increased Speculative Interest to the Dismay of Many Commercial Users." Foodbusinessnews.net, May 13, 2008, http://www.foodbusinessnews.net/feature stories.asp?ArticleID=93497, accessed May 27, 2008.

Tomek, W. G. "Margins on Futures Contracts: Their Economic Roles and Regulation." in Futures Markets: Regulatory Issues, A. E. Peck ed. Washington, D.C., American Enterprise Institute for Public Policy Research, 1985, pp. 143-209.

Trostle, R. "Global Agricultural Supply and Demand: Factors Contributing to the Recent Increase in Food Commodity Prices.” Outlook Report No. WRS-0801, Economic Research Service, U.S. Department of Agriculture, May 2008. (http://www.ers.usda.gov/Publications/WRS0801/WRS0801.pdf)

Working, H. "Futures Trading and Hedging.” American Economic Review 43(1953):314-343.

Working, H. "Whose Markets? Evidence on Some Aspects of Futures Trading." Journal of Marketing 29(1954):1-11.

Working, H. “Speculation on Hedging Markets.” Food Research Institute Studies 1(1960):185-220.

Working, H. "New Concepts Concerning Futures Markets and Prices." American Economic Review 62(1962):432-459. 


\section{Endnotes}

${ }^{1}$ Seen Hieronymus (1971), McDonald and Freund (1983), and Fenton and Martinaitas (2005) for extensive discussions of the history and evolution of the COT Report. CFTC (2008) contains a detailed explanation of current COT reports.

${ }^{2}$ According to Hull (2000, p. 121), "A swap is an agreement between two companies to exchange cash flows in the future. The agreement defines the dates when the cash flows are to be paid and way that they are to be calculated. Usually the calculation of the cash flows involves the future values of one or more market variables." A cash forward contract is a simple example of a swap in commodities markets. Suppose a farmer enters into a forward contract with a grain merchant today to deliver 10,000 bushels of soybeans on October 1, 2008 at $\$ 12$ per bushel. Since the grain merchant can sell the grain as soon as it is delivered by the farmer, the forward contract is equivalent to a "swap" agreement where the grain merchant will pay a cash flow of $\$ 120,000$ on October 1, 2008, and in return, will receive a cash flow of $10,000 \times \mathrm{S}$, where $\mathrm{S}$ is the spot price of soybeans on October 1, 2008. Hull notes that swap agreements typically have cash flows on more than one date, whereas the forward contract "swap" has cash flows on a single date.

${ }^{3}$ CBOT denotes Chicago Board of Trade (now CME Group, Inc.), KCBOT denotes Kansas City Board of Trade, and MGEX, denotes Minneapolis Grain Exchange.

${ }^{4}$ Note that SS $+\mathrm{HS}=\mathrm{SL}+\mathrm{HL}$ must hold in a zero sum futures market if all positions are categorized as speculative or hedging. If $\mathrm{HL}=0$, the identity reduces to $\mathrm{SS}+\mathrm{HS}=\mathrm{SL}$. Dividing through by $\mathrm{HS}$ and re-arranging yields $\mathrm{T}=\mathrm{SL} / \mathrm{HS}=1+(\mathrm{SS} / \mathrm{HS})$.

${ }^{5}$ The 1967 Nathan Associates study reported speculative indexes in graphical form rather than tabular form, and hence, results from this study were not included in Table 9.

${ }^{6}$ Note that CIT adjusted speculative indexes for 2006-2008 in Table 8 allocate non-reporting traders' positions to the commercial, non-commercial, and index trader categories in the same proportion as that which is observed for reporting traders. Consequently, the estimates in Table 8 fall between the reported ranges in Table 9. 
Table 1. Percent of Open Interest Held by Trader Category, COT Reports, 1995-2008

\begin{tabular}{|c|c|c|c|c|c|c|}
\hline \multirow[b]{2}{*}{ Market } & \multirow[b]{2}{*}{$\begin{array}{c}\text { Non- } \\
\text { Commercial }\end{array}$} & \multirow{2}{*}{$\begin{array}{c}\text { 1995-'05 } \\
\text { Commercial }\end{array}$} & \multirow[b]{2}{*}{$\begin{array}{c}\text { Non- } \\
\text { Reporting }\end{array}$} & \multirow[b]{2}{*}{$\begin{array}{c}\text { Non- } \\
\text { Commercial }\end{array}$} & \multirow{2}{*}{$\begin{array}{c}\text { 2006-‘08 } \\
\text { Commercial }\end{array}$} & \multirow[b]{2}{*}{$\begin{array}{c}\text { Non- } \\
\text { Reporting }\end{array}$} \\
\hline & & & & & & \\
\hline Corn & $28 \%$ & $47 \%$ & $25 \%$ & $39 \%$ & $46 \%$ & $15 \%$ \\
\hline Soybeans & $33 \%$ & $42 \%$ & $25 \%$ & $40 \%$ & $44 \%$ & $16 \%$ \\
\hline Soybean Oil & $31 \%$ & $51 \%$ & $18 \%$ & $34 \%$ & $58 \%$ & $8 \%$ \\
\hline CBOT Wheat & $35 \%$ & $42 \%$ & $22 \%$ & $42 \%$ & $48 \%$ & $10 \%$ \\
\hline KCBOT Wheat & $20 \%$ & $55 \%$ & $25 \%$ & $32 \%$ & $48 \%$ & $20 \%$ \\
\hline Cotton & $34 \%$ & $53 \%$ & $13 \%$ & $41 \%$ & $52 \%$ & $7 \%$ \\
\hline Live Cattle & $30 \%$ & $41 \%$ & $29 \%$ & $40 \%$ & $44 \%$ & $16 \%$ \\
\hline Feeder Cattle & $32 \%$ & $24 \%$ & $43 \%$ & $42 \%$ & $27 \%$ & $32 \%$ \\
\hline Lean Hogs & $34 \%$ & $36 \%$ & $30 \%$ & $40 \%$ & $45 \%$ & $15 \%$ \\
\hline
\end{tabular}

Table 2. Original COT Classification for CIT Positions, 2006-2008

\begin{tabular}{lccccc} 
Market & $\begin{array}{c}\text { Non- } \\
\text { Commercial } \\
\text { Long }\end{array}$ & $\begin{array}{c}\text { Non- } \\
\text { Commercial } \\
\text { Short }\end{array}$ & $\begin{array}{c}\text { Non- } \\
\text { Commercial } \\
\text { Spread }\end{array}$ & $\begin{array}{c}\text { Commercial } \\
\text { Long }\end{array}$ & $\begin{array}{c}\text { Commercial } \\
\text { Short }\end{array}$ \\
\hline Corn & $11 \%$ & $0 \%$ & $0 \%$ & $86 \%$ & $3 \%$ \\
Soybeans & $10 \%$ & $0 \%$ & $0 \%$ & $87 \%$ & $3 \%$ \\
Soybean Oil & $7 \%$ & $0 \%$ & $0 \%$ & $91 \%$ & $2 \%$ \\
CBOT Wheat & $11 \%$ & $0 \%$ & $0 \%$ & $84 \%$ & $5 \%$ \\
KCBOT Wheat & $15 \%$ & $0 \%$ & $0 \%$ & $84 \%$ & $1 \%$ \\
Cotton & $8 \%$ & $0 \%$ & $0 \%$ & $90 \%$ & $2 \%$ \\
Live Cattle & $15 \%$ & $0 \%$ & $0 \%$ & $83 \%$ & $1 \%$ \\
Feeder Cattle & $36 \%$ & $0 \%$ & $0 \%$ & $63 \%$ & $1 \%$ \\
Lean Hogs & $14 \%$ & $0 \%$ & $0 \%$ & $86 \%$ & $1 \%$ \\
\hline
\end{tabular}

Table 3. Percent of Open Interest Held by COT Groups, 2006-2008

\begin{tabular}{lcccc} 
Market & $\begin{array}{c}\text { Non- } \\
\text { Commercial }\end{array}$ & Commercial & Index & Non-Reporting \\
\hline Corn & $37 \%$ & $36 \%$ & $12 \%$ & $15 \%$ \\
Soybeans & $38 \%$ & $33 \%$ & $13 \%$ & $16 \%$ \\
Soybean Oil & $33 \%$ & $46 \%$ & $12 \%$ & $8 \%$ \\
CBOT Wheat & $39 \%$ & $29 \%$ & $21 \%$ & $10 \%$ \\
KCBOT Wheat & $30 \%$ & $40 \%$ & $10 \%$ & $20 \%$ \\
Cotton & $40 \%$ & $37 \%$ & $16 \%$ & $7 \%$ \\
Live Cattle & $37 \%$ & $28 \%$ & $20 \%$ & $16 \%$ \\
Feeder Cattle & $37 \%$ & $19 \%$ & $12 \%$ & $32 \%$ \\
Lean Hogs & $37 \%$ & $26 \%$ & $22 \%$ & $15 \%$ \\
\hline
\end{tabular}


Table 4. Percent Net Long by COT Trader Groups, 2006-2008

\begin{tabular}{lcccc} 
Market & $\begin{array}{c}\text { Non- } \\
\text { Commercial }\end{array}$ & Commercial & Index & Non-Reporting \\
\hline Corn & $48 \%$ & $-37 \%$ & $94 \%$ & $-19 \%$ \\
Soybeans & $28 \%$ & $-35 \%$ & $94 \%$ & $-18 \%$ \\
Soybean Oil & $46 \%$ & $-42 \%$ & $95 \%$ & $22 \%$ \\
CBOT Wheat & $-6 \%$ & $-54 \%$ & $90 \%$ & $-25 \%$ \\
KCBOT Wheat & $66 \%$ & $-47 \%$ & $98 \%$ & $-11 \%$ \\
Cotton & $15 \%$ & $-47 \%$ & $96 \%$ & $28 \%$ \\
Live Cattle & $21 \%$ & $-57 \%$ & $97 \%$ & $-39 \%$ \\
Feeder Cattle & $33 \%$ & $-20 \%$ & $98 \%$ & $-45 \%$ \\
Lean Hogs & $-7 \%$ & $-65 \%$ & $98 \%$ & $-24 \%$ \\
\hline
\end{tabular}

Table 5. Percent of Long and Short Positions by COT Trader Group, 2006-2008.

Panel A: Long Positions

\begin{tabular}{lcccc} 
Market & $\begin{array}{c}\text { Non- } \\
\text { Commercial }\end{array}$ & Commercial & Index & Non-Reporting \\
\hline Corn & $42 \%$ & $23 \%$ & $23 \%$ & $12 \%$ \\
Soybeans & $41 \%$ & $21 \%$ & $25 \%$ & $13 \%$ \\
Soybean Oil & $39 \%$ & $27 \%$ & $24 \%$ & $10 \%$ \\
CBOT Wheat & $39 \%$ & $14 \%$ & $40 \%$ & $8 \%$ \\
KCBOT Wheat & $41 \%$ & $21 \%$ & $20 \%$ & $18 \%$ \\
Cotton & $40 \%$ & $20 \%$ & $31 \%$ & $9 \%$ \\
Live Cattle & $40 \%$ & $12 \%$ & $39 \%$ & $10 \%$ \\
Feeder Cattle & $44 \%$ & $16 \%$ & $23 \%$ & $17 \%$ \\
Lean Hogs & $36 \%$ & $9 \%$ & $44 \%$ & $12 \%$ \\
\hline
\end{tabular}

Panel B: Short Positions

\begin{tabular}{lcccc} 
Market & $\begin{array}{c}\text { Non- } \\
\text { Commercial }\end{array}$ & Commercial & Index & Non-Reporting \\
\hline Corn & $33 \%$ & $49 \%$ & $1 \%$ & $18 \%$ \\
Soybeans & $36 \%$ & $45 \%$ & $1 \%$ & $19 \%$ \\
Soybean Oil & $27 \%$ & $66 \%$ & $1 \%$ & $7 \%$ \\
CBOT Wheat & $40 \%$ & $45 \%$ & $2 \%$ & $13 \%$ \\
KCBOT Wheat & $19 \%$ & $58 \%$ & $0 \%$ & $22 \%$ \\
Cotton & $39 \%$ & $55 \%$ & $1 \%$ & $5 \%$ \\
Live Cattle & $34 \%$ & $44 \%$ & $0 \%$ & $22 \%$ \\
Feeder Cattle & $31 \%$ & $23 \%$ & $0 \%$ & $46 \%$ \\
Lean Hogs & $38 \%$ & $42 \%$ & $0 \%$ & $19 \%$ \\
\hline
\end{tabular}


Table 6. Average Number of Reporting Traders, COT Trader Category, 2006-2008

\begin{tabular}{|c|c|c|c|c|c|c|c|c|}
\hline \multirow[b]{2}{*}{ Market } & \multirow[b]{2}{*}{ Total } & \multicolumn{3}{|c|}{ Non-Commercial } & \multicolumn{2}{|c|}{ Commercial } & \multirow{2}{*}{$\frac{\text { Index }}{\text { Long }}$} & \multirow{2}{*}{$\begin{array}{l}\text { Index } \\
\text { Short }\end{array}$} \\
\hline & & Long & Short & Spread & Long & Short & & \\
\hline Corn & 758 & 203 & 133 & 234 & 275 & 331 & 24 & 10 \\
\hline Soybeans & 463 & 138 & 111 & 166 & 113 & 152 & 24 & 7 \\
\hline Soybean Oil & 197 & 64 & 38 & 55 & 49 & 57 & 16 & 3 \\
\hline CBOT Wheat & 370 & 102 & 118 & 142 & 65 & 101 & 24 & 9 \\
\hline KCBOT Wheat & 182 & 57 & 24 & 37 & 50 & 72 & 15 & 2 \\
\hline Cotton & 297 & 112 & 78 & 87 & 63 & 62 & 21 & 4 \\
\hline Live Cattle & 328 & 79 & 68 & 87 & 80 & 137 & 23 & 3 \\
\hline Feeder Cattle & 146 & 35 & 29 & 29 & 35 & 51 & 16 & 1 \\
\hline Lean Hogs & 213 & 57 & 68 & 80 & 24 & 43 & 21 & 2 \\
\hline
\end{tabular}

Table 7. Average Position Size (contracts), COT Trader Category, 2006-2008

\begin{tabular}{|c|c|c|c|c|c|c|c|c|c|}
\hline \multirow[b]{2}{*}{ Market } & \multicolumn{3}{|c|}{ Non-Commercial } & \multicolumn{2}{|c|}{ Commercial } & \multirow{2}{*}{$\frac{\text { Index }}{\text { Long }}$} & \multirow{2}{*}{$\frac{\text { Index }}{\text { Short }}$} & \multirow{2}{*}{$\begin{array}{c}\text { Reportable } \\
\text { Position }\end{array}$} & \multirow{2}{*}{$\begin{array}{l}\text { Spec. } \\
\text { Limit }^{\mathrm{a}}\end{array}$} \\
\hline & Long & Short & Spread & Long & Short & & & & \\
\hline Corn & 1,218 & 644 & 2,062 & 1,422 & 2,542 & 16,805 & 1,176 & 250 & 22,000 \\
\hline Soybeans & 616 & 398 & 955 & 1,081 & 1,743 & 6,123 & 691 & 150 & 10,000 \\
\hline Soybean Oil & 861 & 483 & 1123 & 1,647 & 3,527 & 4,550 & 688 & 200 & 6,500 \\
\hline CBOT Wheat & 573 & 553 & 981 & 1,091 & 2,297 & 8,597 & 1,092 & 150 & 6,500 \\
\hline KCBOT Wheat & 723 & 349 & 549 & 626 & 1,223 & 1,948 & 180 & 150 & 6,500 \\
\hline Cotton & 382 & 393 & 891 & 921 & 2,652 & 4,104 & 361 & 100 & 5,000 \\
\hline Live Cattle & 566 & 434 & 722 & 408 & 864 & 4,569 & 462 & 100 & 5,150 \\
\hline Feeder Cattle & 267 & 152 & 203 & 153 & 153 & 473 & 62 & 50 & 1,000 \\
\hline Lean Hogs & 401 & 394 & 565 & 754 & 1,885 & 3,853 & 212 & 100 & 4,100 \\
\hline
\end{tabular}

${ }^{\mathrm{a}}$ Limits for futures plus delta-adjusted options positions, all contract months combined.

Table 8. Working's Speculative Index, 1996-2008

\begin{tabular}{|c|c|c|c|c|c|}
\hline Market & $\begin{array}{c}C O T \\
1995-{ }^{`} 01\end{array}$ & $\begin{array}{c}C O T \\
2002-{ }^{`} 03\end{array}$ & $\begin{array}{c}C O T \\
2004-{ }^{`} 05\end{array}$ & $\begin{array}{c}C O T \\
2006-{ }^{`} 08\end{array}$ & $\begin{array}{l}\text { CIT Adjusted } \\
2006-^{-} 08\end{array}$ \\
\hline Corn & 1.06 & 1.09 & 1.10 & 1.07 & 1.13 \\
\hline Soybeans & 1.08 & 1.08 & 1.10 & 1.09 & 1.21 \\
\hline Soybean Oil & 1.07 & 1.07 & 1.07 & 1.06 & 1.09 \\
\hline CBOT Wheat & 1.13 & 1.15 & 1.15 & 1.14 & 1.31 \\
\hline KCBOT Wheat & 1.05 & 1.05 & 1.09 & 1.09 & 1.14 \\
\hline Cotton & 1.05 & 1.05 & 1.09 & 1.10 & 1.20 \\
\hline Live Cattle & 1.12 & 1.13 & 1.11 & 1.15 & 1.30 \\
\hline Feeder Cattle & 1.28 & 1.31 & 1.26 & 1.38 & 1.67 \\
\hline Lean Hogs & 1.23 & 1.15 & 1.13 & 1.16 & 1.39 \\
\hline Average & 1.12 & 1.12 & 1.12 & 1.14 & 1.27 \\
\hline
\end{tabular}


Table 9. Working's Speculative Index Reported in Prior Research

\begin{tabular}{|c|c|c|c|c|c|c|}
\hline Market & $\begin{array}{c}\text { Working }^{a} \\
1954-1958\end{array}$ & $\begin{array}{c}\text { Labys \& } \\
\text { Granger }^{b} \\
1950-1965\end{array}$ & $\begin{array}{c}\text { Peck }^{\mathrm{c}} \\
1947-1971\end{array}$ & $\begin{array}{c}\text { Peck }^{\mathrm{c}} \\
1972-1977\end{array}$ & $\begin{array}{c}\text { Leuthold }^{d} \\
\text { 1969-1980 }\end{array}$ & $\begin{array}{l}\text { CIT Adjusted } \\
\text { 2006-'08 }\end{array}$ \\
\hline Corn & 1.16 & 1.19 & $1.263-1.609$ & $1.045-1.204$ & & $1.06-1.34$ \\
\hline Soybeans & 1.28 & 1.31 & $1.329-1.946$ & $1.061-1.310$ & & $1.10-1.45$ \\
\hline Soybean Oil & 1.14 & 1.18 & & & & $1.07-1.15$ \\
\hline CBOT Wheat & 1.22 & 1.19 & $1.355-1.891$ & $1.094-1.323$ & & $1.19-1.49$ \\
\hline KCBOT Wheat & & & $1.081-1.264$ & $1.009-1.045$ & & $1.05-1.36$ \\
\hline Cotton & 1.27 & & & & & $1.16-1.27$ \\
\hline Live Cattle & & & & $1.568-2.173$ & $1.05-2.34$ & $1.13-1.60$ \\
\hline Feeder Cattle & & & & & $1.08-3.80$ & $1.14-2.61$ \\
\hline Lean Hogs & & & & & $1.10-8.69$ & $1.18-1.68$ \\
\hline Average & 1.21 & 1.22 & $1.26-1.68$ & $1.155-1.411$ & $1.08-4.94$ & $1.12-1.55$ \\
\hline
\end{tabular}

${ }^{a}$ Working (1960), Table 3, p. 194. Non-reporting traders are allocated to hedging or speculating based on the levels of hedging and speculating in reported positions (see Working's technical appendix 2, p.p. 214-216)

${ }^{b}$ Laby's and Ganger (1970), Table 5-6, p. 127. Non-reporting traders are allocated to hedging or speculating based on the levels of hedging and speculating in reported positions following the method of Working (1960).

${ }^{c}$ Peck (1980), Table 1, p. 1039 and Table 2, p. 1042. Peck estimates an upper (lower) bound by assuming all nonreporting traders are speculators (hedgers). The date range represents the most inclusive time period over which the index was calculated across the markets.

${ }^{\mathrm{d}}$ Leuthold (1983), Table VI, p. 131. Leuthold estimates an upper (lower) bound by assuming all non-reporting traders are speculators (hedgers). The date range represents the most inclusive time period over which the index was calculated across the markets.

${ }^{\mathrm{e}}$ Upper (lower) range results from assuming that non-reporting traders are speculators (hedgers).

Table 10. Bank Participation Data, 2006-2008

\begin{tabular}{lccccc} 
Market & $\begin{array}{c}\text { Bank } \\
\text { Count }\end{array}$ & $\begin{array}{c}\text { \% of Futures } \\
\text { Open Interest }\end{array}$ & $\begin{array}{c}\text { Position Size } \\
\text { Long }\end{array}$ & $\begin{array}{c}\text { Position Size } \\
\text { Short }\end{array}$ & $\begin{array}{c}\text { \% of CIT } \\
\text { Open Interest }\end{array}$ \\
\hline Corn & 13 & $5 \%$ & 10,057 & 551 & $31 \%$ \\
Soybeans & 10 & $4 \%$ & 3,555 & 259 & $25 \%$ \\
Soybean Oil & 7 & $4 \%$ & 2,634 & 192 & $27 \%$ \\
CBOT Wheat & 14 & $9 \%$ & 4,970 & 425 & $35 \%$ \\
KCBOT Wheat & 7 & $3 \%$ & 1,147 & 22 & $26 \%$ \\
Cotton & 10 & $6 \%$ & 2,093 & 56 & $25 \%$ \\
Live Cattle & 7 & $5 \%$ & 3,333 & 245 & $25 \%$ \\
Feeder Cattle & 5 & $2 \%$ & 231 & 29 & $18 \%$ \\
Lean Hogs & 7 & $5 \%$ & 2,795 & 20 & $22 \%$ \\
\hline
\end{tabular}


Figure 1. Combined Futures and Options Open Interest for CBOT Wheat, 1995-2008

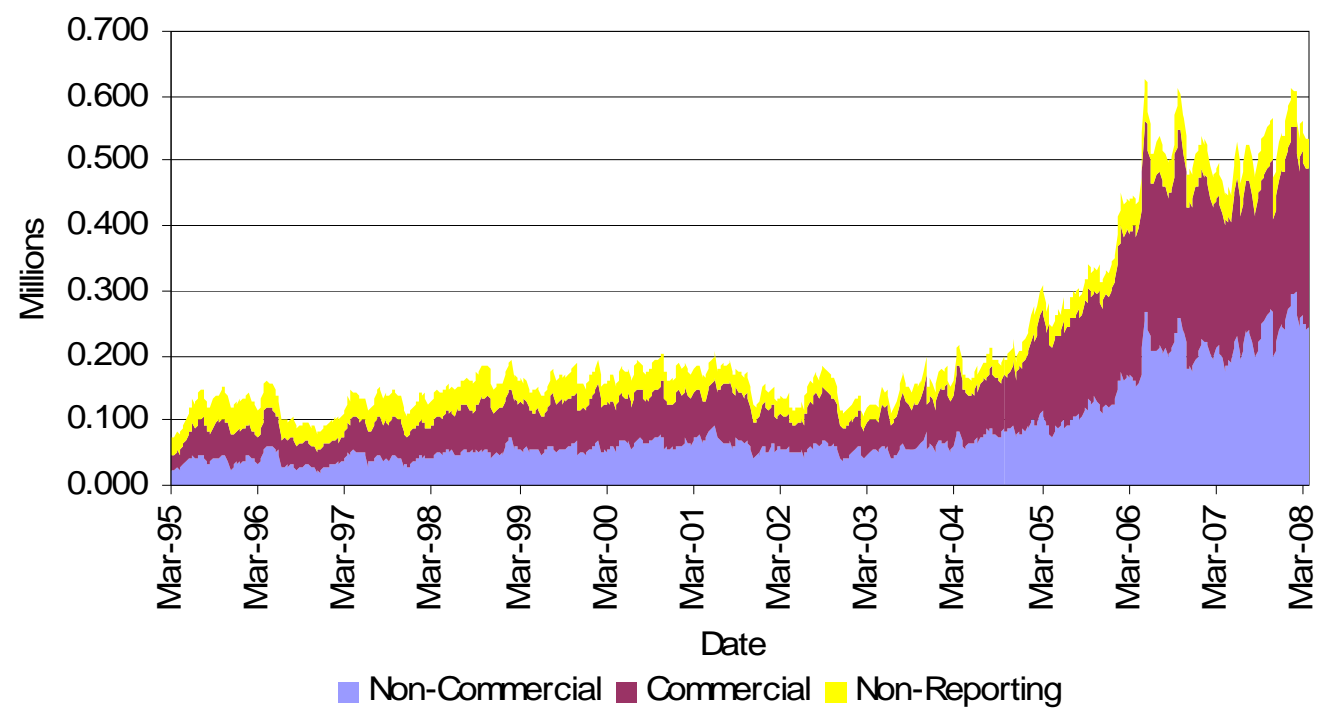

Figure 2. Combined Futures and Options Open Interest for Soybeans, 1995-2008

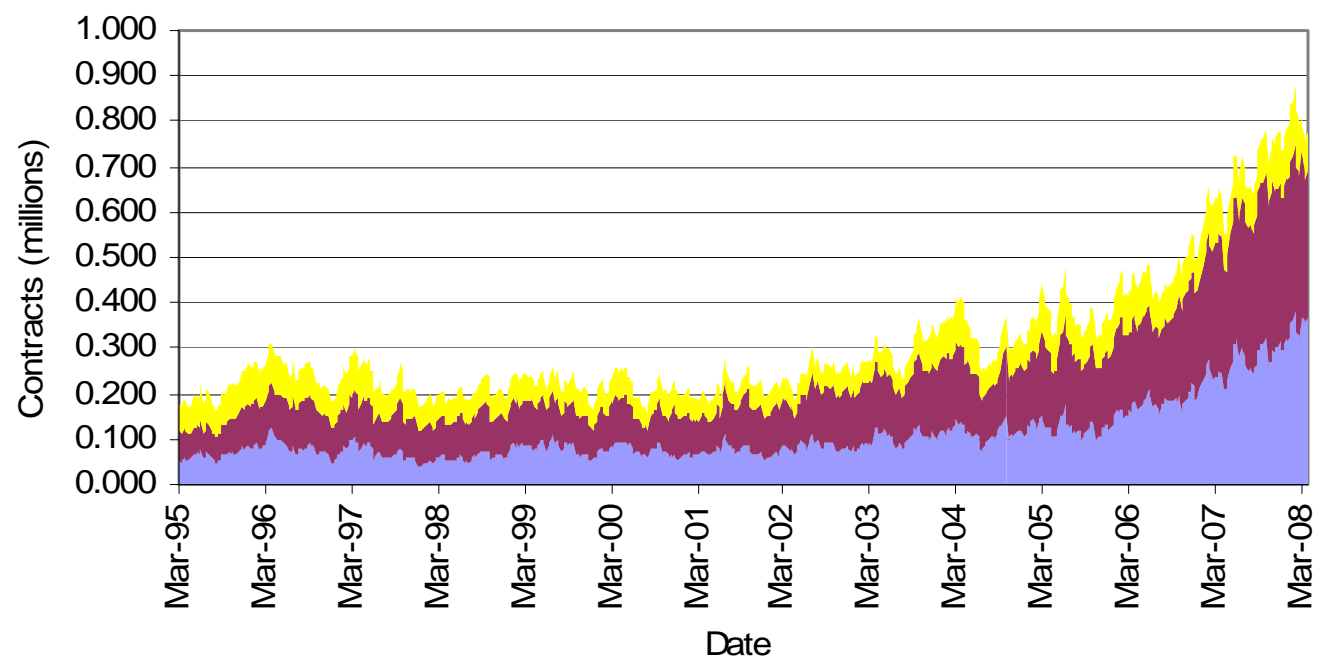

$\square$ Non-Commercial $\square$ Commercial $\square$ Non-Reporting 
Figure 3. Percent of Open Interest for CBOT Wheat by COT Category, 1995-2008

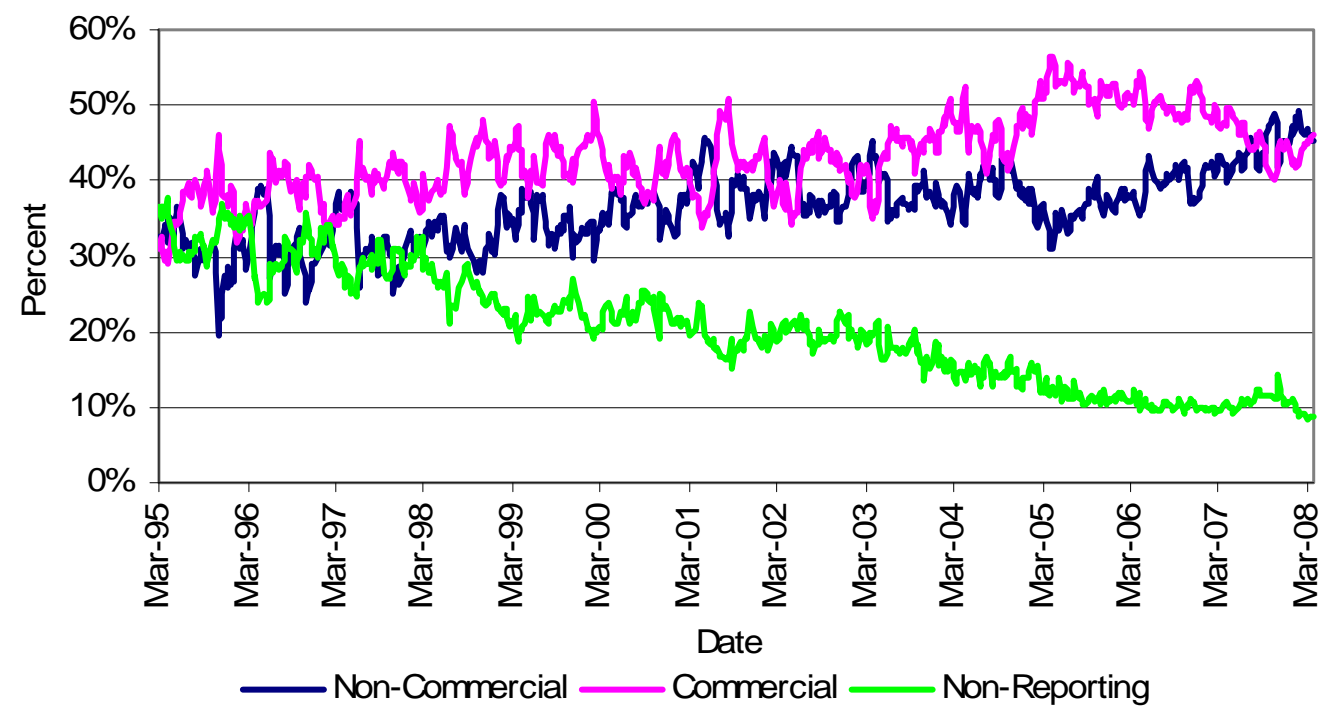

Figure 4. Percent of Open Interest for CBOT Wheat by COT Category, 2006-2008

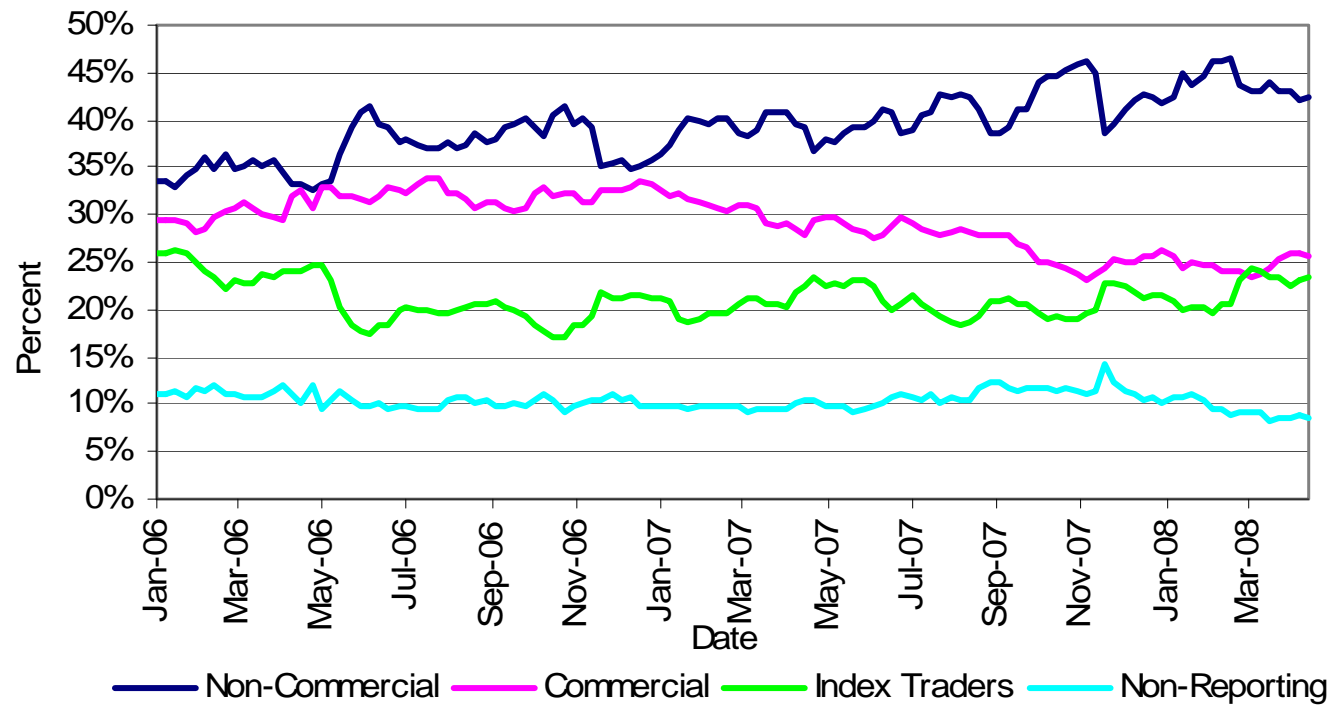


Figure 5. Percent of Open Interest in CBOT Wheat, Corn, and Soybeans Held by CIT Traders, 2006-2008

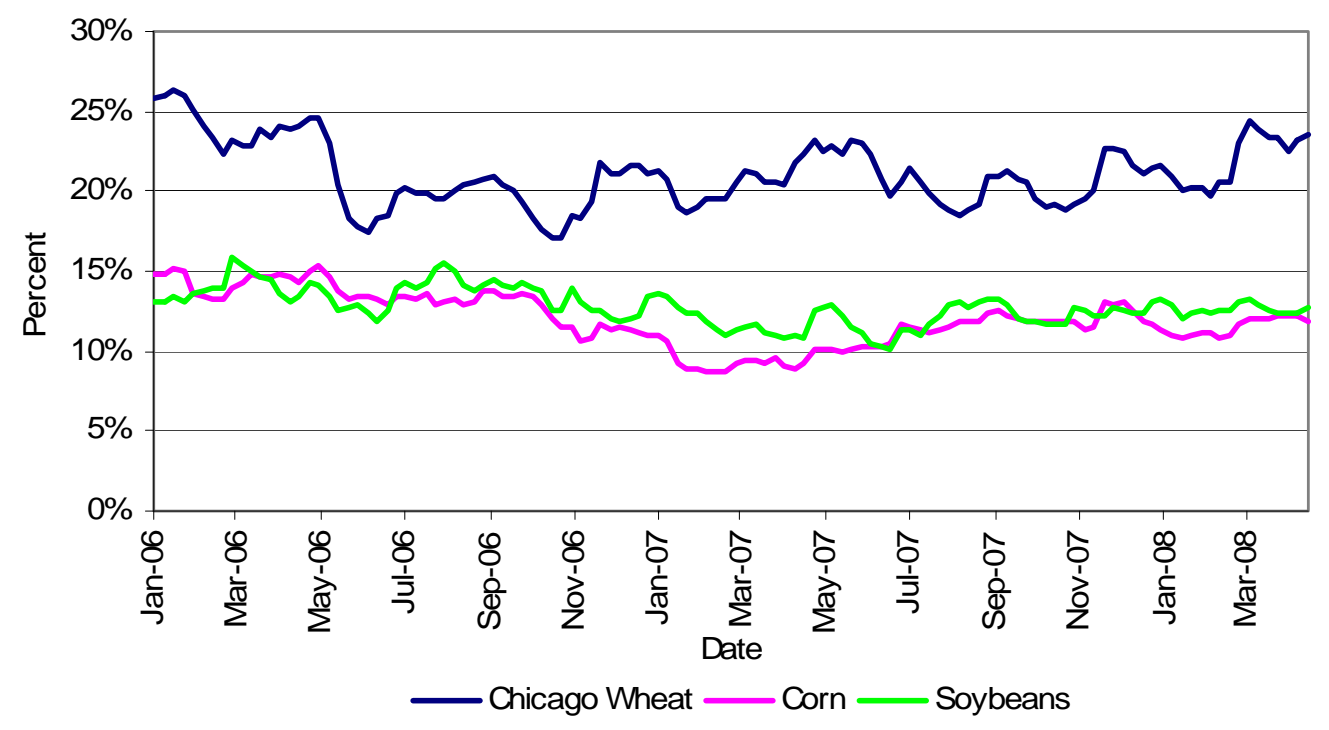

Figure 6. Percent of Open Interest in Live Cattle, Lean Hogs and Feeder Cattle Held by CIT Traders, 2006-2008

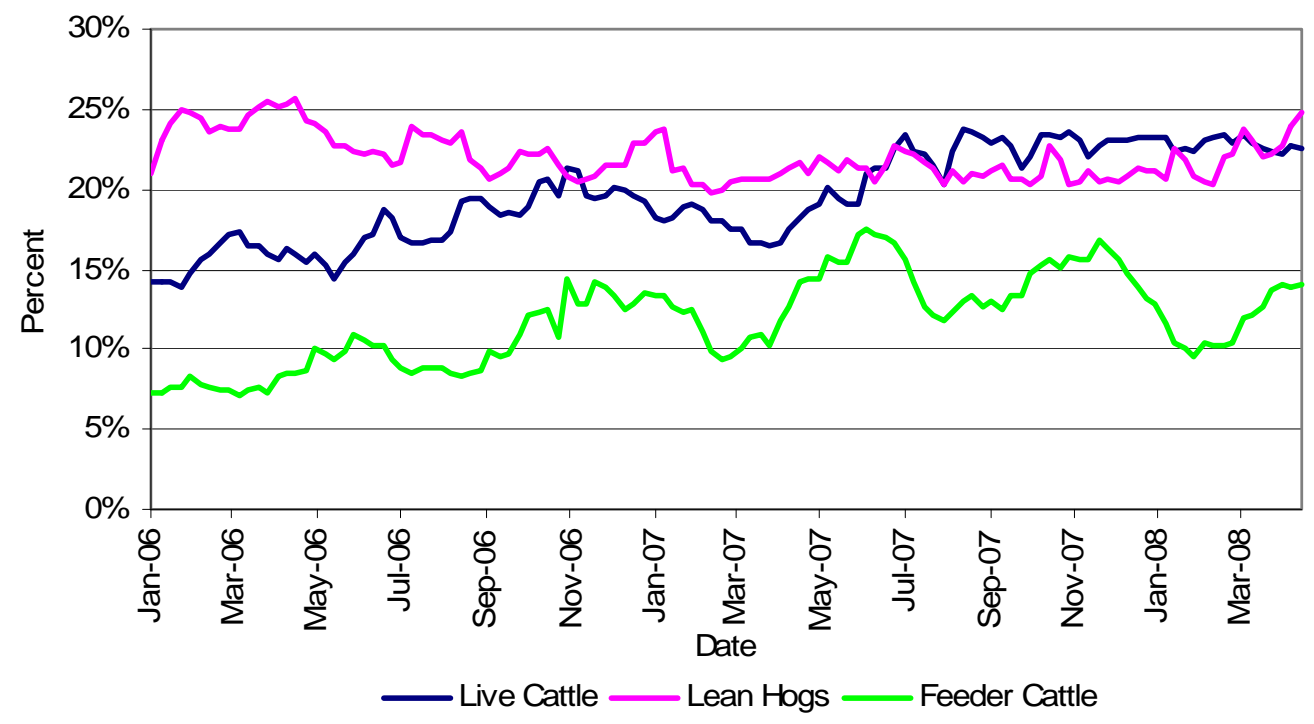


Figure 7. Working's Speculative Index for CBOT Wheat, Original COT Data, 1995-2008

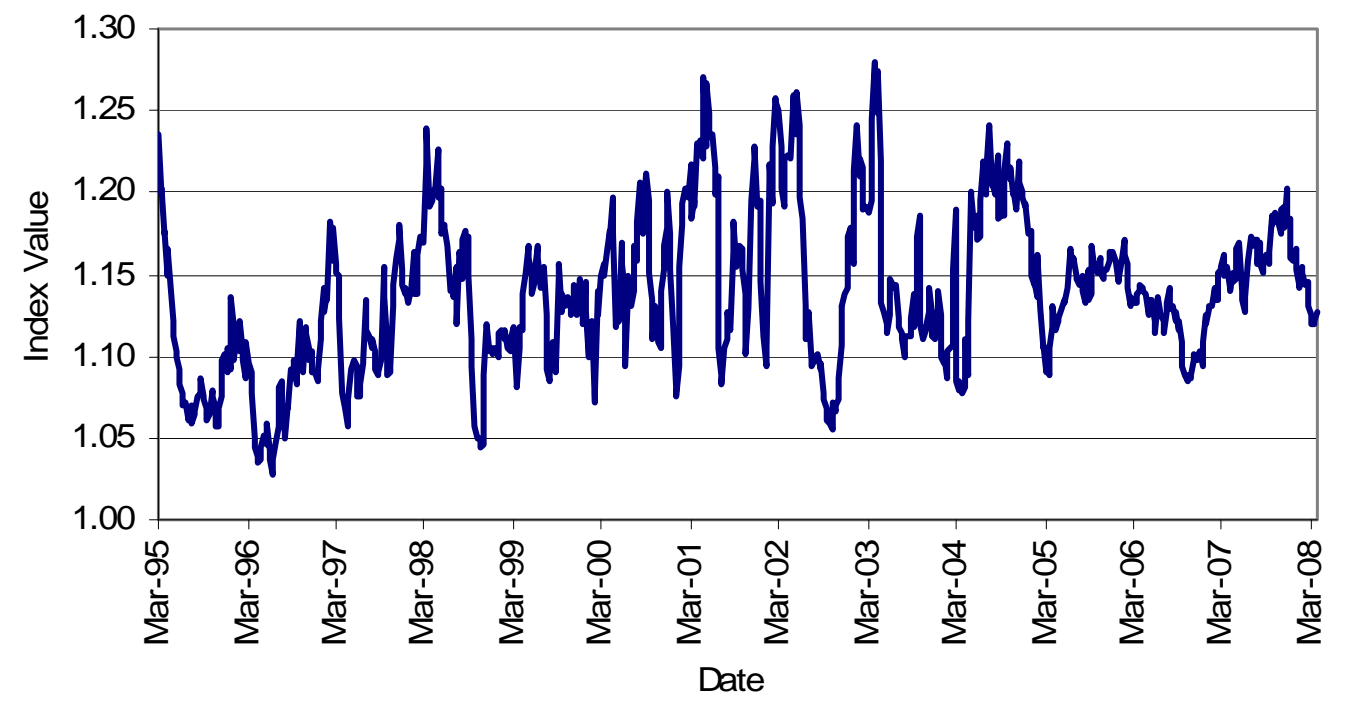

Figure 8. CIT and Bank Positions in Corn, 2005-2008

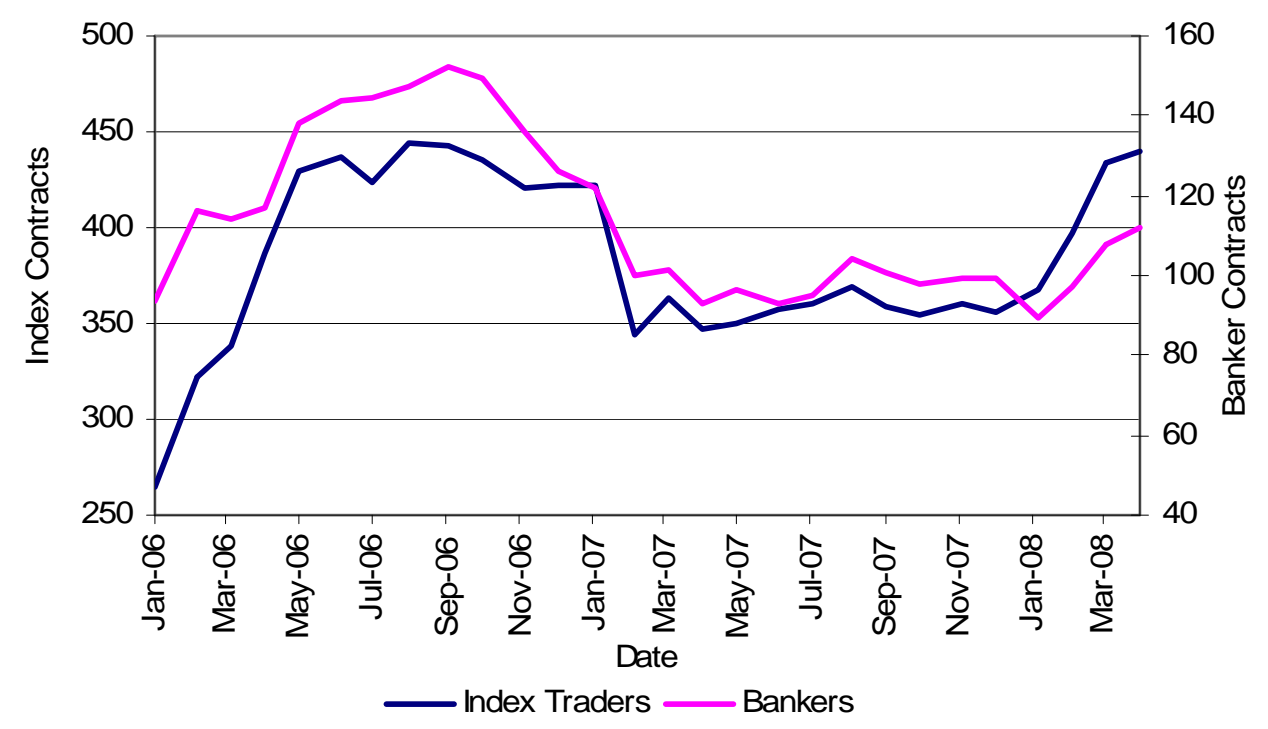


Figure 9. Bank Percent of Futures Open Interest in CBOT Wheat, Corn, and Soybeans, 2003-2008

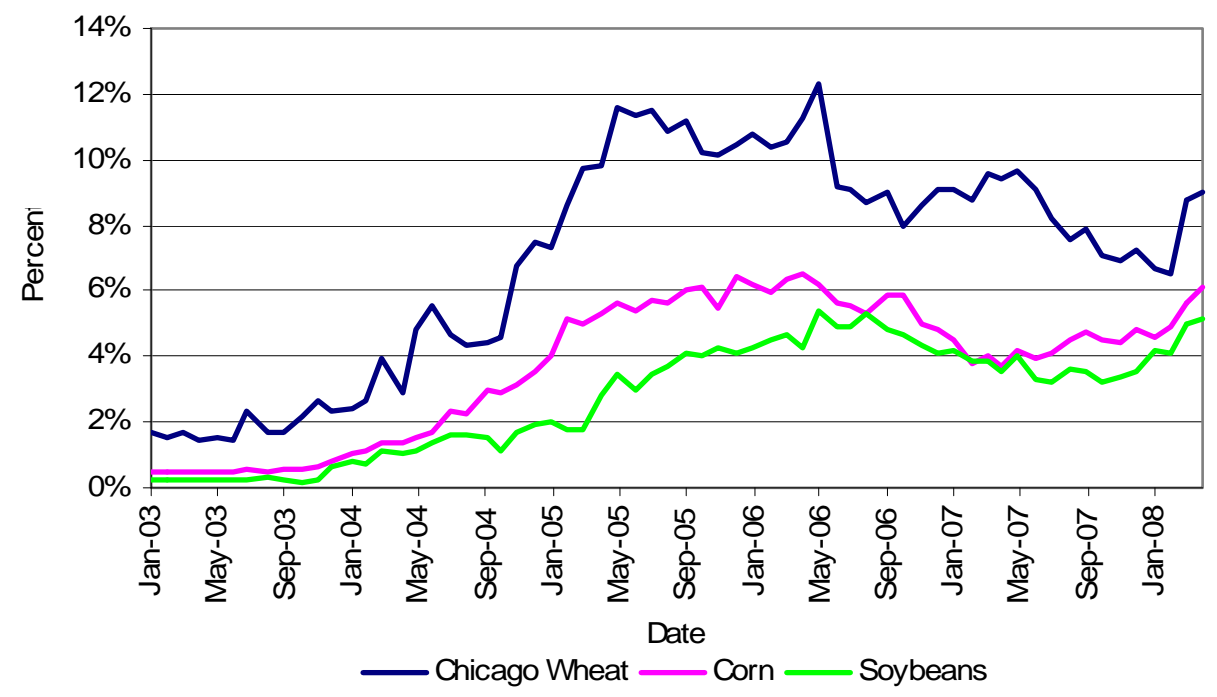

Figure 10. Bank Participation in Soybeans, 2003-2008

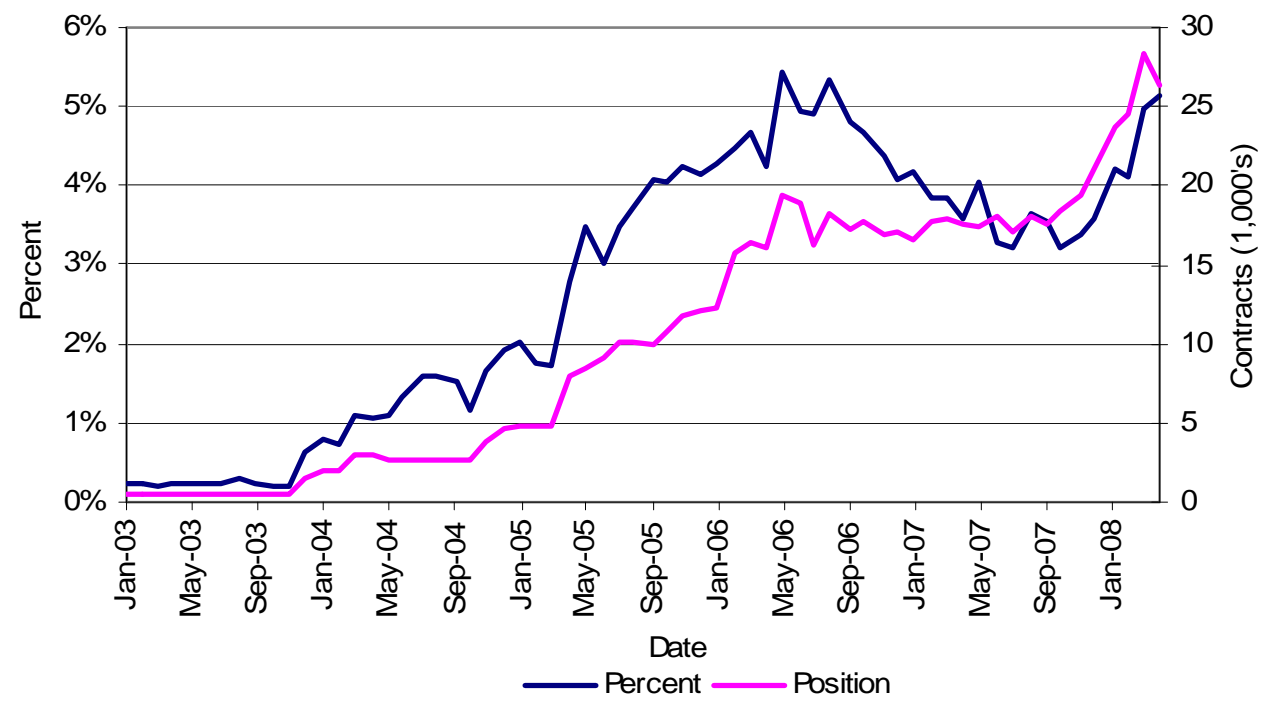


Figure 11. CIT Participation in Soybeans, 2006-2008.

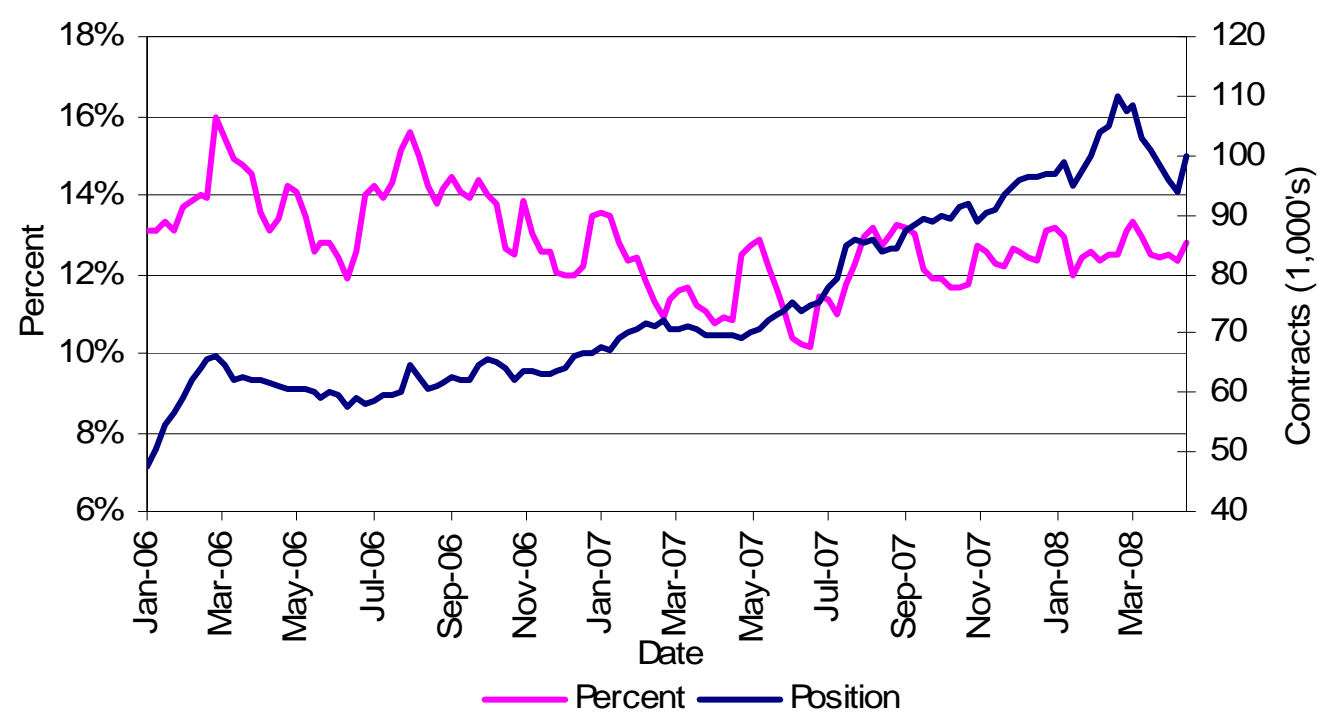

Figure 12. CIT Participation in Lean Hogs, 2006-2008.

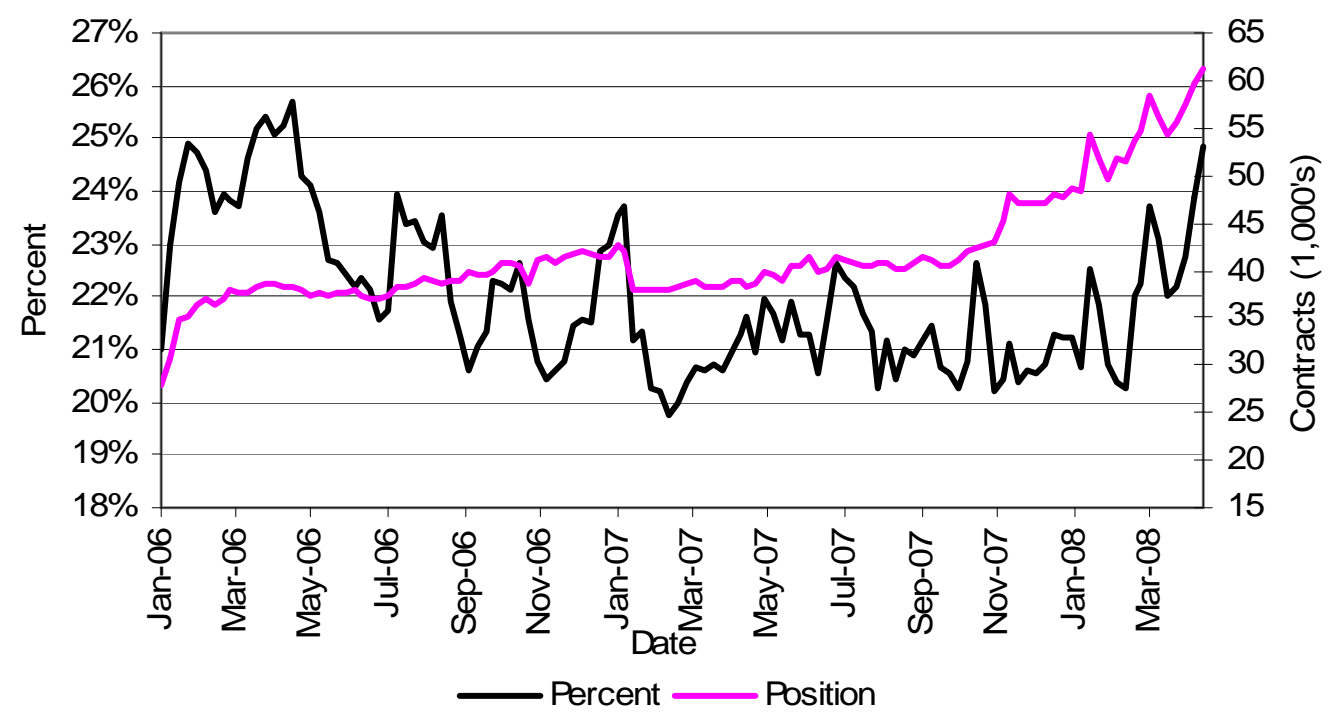

